\title{
Estimasi Gaya Dorong Dari Motor Brushless Dengan Variasi Propeller Untuk Pesawat Model X-UAV Mini Talon Dengan Menggunakan Pengukur Massa
}

\author{
Ananda Rafi Rijalul Awwal*(1), Mufti Arifin ${ }^{(2)}$, Endah Yuniarti( ${ }^{(3)}$ \\ (1)(2)(3)Prodi Teknik Penerbangan, Fakultas Teknologi Kedirgantaraan, \\ Universitas Dirgantara Marsekal Suryadarma \\ Kompleks Bandara Perdana Kusuma, Jakarta 13610, Indonesia \\ ${ }^{*}$ Corresponding Author : anandarafi25@gmail.com
}

\begin{abstract}
Abstrak - Salah satu yang mempengaruhi performa pesawat ialah gaya dorong (thrust). Gaya dorong ditentukan sesuai keperluan dari pesawat terbang itu sendiri. Penelitian ini menggunakan alat thrust test stand yang menggunakan alat pengukur massa sebagai pengukur gaya dorong, dengan menggunakan dua buah motor brushless dan lima buah propeller untuk menentukan gaya dorong yang optimal untuk misi terbang pesawat X-UAV Mini Talon. Gaya dorong yang dibutuhkan pesawat X-UAV Mini Talon -diketahui sebesar $0,6755 \mathrm{~N}$ untuk terbang jelajah (cruise) dan 4,979 $\mathrm{N}$ untuk pesawat dapat take-off. Setelah dilakukan pengujian, didapatkan gaya dorong terkecil dihasilkan oleh konfigurasi motor brushless DYS 2826-13 dengan propeller $5 \times 3$ inch, sedangkan gaya dorong terbesar oleh motor brushless RacerStar BR2212 dengan propeller 10x6 inch. Dibandingkan dengan perhitungan dengan persamaan gaya dorong statis propeller maka selisih gaya dorong pada pengujian dengan gaya dorong statis propeller berkisar antara $15 \%$ sampai $25 \%$. Maka dari itu, konfigurasi yang optimal untuk terbang jelajah adalah motor brushless DYS 2826-13 dengan propeller $5 \times 3$ inch, yang menghasilkan gaya dorong sebesar 0,988 N. Kemudian, untuk take-off konfigurasi yang optimal adalah Brushless DYS 2826-13 dengan propeller 9x5 inch, yang menghasilkan gaya dorong sebesar 6,151 . Konfigurasi diatas dipilih karena lebih efisien, dengan kebutuhan arus yang lebih kecil dibandingkan konfigurasi lain dengan gaya dorong yang kurang lebih setara.
\end{abstract}

Kata kunci : gaya dorong, pesawat model, pengukur massa, brushless, propeller.

Abstract - One that affects aircraft performance is the thrust. The thrust is determined according to the requirements of the aircraft itself. This study uses a thrust test stand that uses a mass gauge as a thrust gauge, using two brushless motors and five propellers to determine the optimal thrust for X-UAV Mini Talon aircraft flying missions. The thrust required by the $X-$ UAV Mini Talon aircraft - is known to be $0.6755 \mathrm{~N}$ for cruise flights and $4.979 \mathrm{~N}$ for take-off aircraft. After testing, the smallest thrust is produced by the configuration of the DYS 2826-13 brushless motor with a $5 \times 3$ inch propeller, while the biggest thrust by the RacerStar BR2212 brushless motor with a 10x6 inch propeller. Compared to calculations with propeller static thrust equation, the difference in thrust in testing with propeller static thrust ranges from $15 \%$ to $25 \%$. Therefore, the optimal configuration for flying cruising is the DYS 2826-13 brushless motor with a $5 \times 3$ inch propeller, which produces a thrust of $0.988 \mathrm{~N}$. Then, for the optimal configuration take-off is the Brushless DYS 2826-13 with a 9x5 inch propeller, which results in a thrust of 6,151. The configuration above was chosen because it is more efficient, with smaller current requirements compared to other configurations with more or less equivalent thrust. 
Keyword : thrust, model aircraft, mass gauge, brushless, propeller.

\section{PENDAHULUAN}

Gaya dorong ditentukan sesuai keperluan dari pesawat terbang itu sendiri, apakah digunakan untuk keperluan jet tempur, jet transport, pesawat angkut militer, pesawat pertanian, pesawat dengan dua mesin hingga pesawat buatan rumahan. Gaya dorong dari masingmasing keperluan berbeda-beda, karena kecepatan dari masing-masing pesawat pun berbeda-beda. Maka dari itu, dalam penelitian ini akan dilakukan pengukuran gaya dorong yang dibutuhkan terhadap berat pesawat terbang. Pada penelitian ini akan digunakan pesawat model (aeromodelling) sebagai contoh dari pengukuran gaya dorong terhadap berat pesawat terbang. Pada penelitian ini, akan dihitung gaya dorong yang diperlukan pesawat model X-UAV Mini Talon menggunakan pengukur massa.

Pesawat model X-UAV Mini Talon sendiri merupakan pesawat model yang bisa digunakan untuk keperluan terbang First Person View (FPV) dan juga pemotretan udara. Pada penelitian ini pesawat model X-UAV Mini Talon digunakan untuk keperluan pemotretan dan pemetaan wilayah, dimana tidak membutuhkan kecepatan yang tinggi tapi harus mampu untuk menerbangkan pesawat model yang cukup berat, karena membawa beban berupa kamera untuk pemotretan.

Penentuan gaya dorong yang dibutuhkan oleh pesawat model dilakukan dengan menghitung berapa besar berat terbang pesawat model tersebut. Setelah mengetahui berat terbang akan didapatkan Coefficient of Lift dari pesawat tersebut, yang akan digunakan untuk dapat mengetahui Coefficient of Drag dan mengetahui Drag pesawat tersebut. Setelah diketahui Drag maka akan diketahui berapa gaya dorong yang dibutuhkan baik untuk terbang cruise maupun untuk Take-off.

Pemilihan brushless dan propeller ini bertujuan agar tidak terjadi kekurangan gaya dorong yang menyebabkan pesawat model tidak bisa terbang. Pada penelitian ini akan diuji gaya dorong dari 2 (dua) macam motor brushless dan 5 (lima) variasi propeller. Untuk mengetahui gaya dorong yang dihasilkan dari masingmasing konfigurasi antara motor brushless dan propeller dibutuhkan sebuah alat uji, yaitu thrust test stand. Pada penelitian ini digunakan pengukur massa sebagai parameter gaya dorong yang dihasilkan. Pada nantinya hasil dari penelitian dapat digunakan untuk menentukan motor brushless mana yang optimal untuk X-UAV Mini Talon, sehingga dapat terbang dengan aman.

Penelitian ini didasarkan oleh penelitian yang dilakukan sebelumnya oleh Arkadiusz Jakubowski, B. Minorowicz dan Arkadiusz Kubacki mengenai analisis gaya dorong dari berbagai jenis propeller. Pada penelitian tersebut disimpulkan bahwa gaya dorong meningkat seiring dengan meingkatnya diameter propeller. Menurut data penelitian tersebut, gaya dorong maksimum sebanding dengan diameter propeller yang paling besar. Sedangkan pada diameter yang sama dengan jumlah bilah yang berbeda, tidak memiliki pengaruh yang signifikan. ${ }^{[1]}$

\section{METODE PENELITIAN}

Dalam penelitian ini ada beberapa langkah yang dilakukan, seperti langkah pertama yang akan dilakukan adalah mengetahui berat pesawat terbang tersebut, termasuk komponen-komponen elektronik di dalamnya. Langkah selanjutnya ialah mengestimasi masing- 
Jurnal Teknologi Kedirgantaraan, Vol, V No. 2, Agustus 2020, P-ISSN 2528-2778, E-ISSN 2684-9704 https://doi.org/10.35894/jtk.v5i2.16

masing gaya dorong dari konfigurasi antara motor brushless dan propeller. Lalu selanjutnya adalah memilih konfigurasi mana yang paling cocok digunakan pada pesawat X-UAV Mini Talon.

\subsection{Spesifikasi Pesawat Model X-UAV Mini Talon}

X-UAV Mini Talon merupakan pesawat model yang diproduksi oleh perusahaan HOOAH Aiation Technology, perusahaan teknologi tinggi, khusus dalam penelitian drone, pengembangan, produksi dan penjualan. Berikut ini adalah spesifikasi pesawat X-UAV Mini Talon ${ }^{[9]}$ :
- Wingspan
: $1.300 \mathrm{~mm}$
- Panjang
: $830 \mathrm{~mm}$
- Berat kosong
: 550 gram
- Berat terbang
$: 1000-2000$ gram

- Sistem penggerak : Motor

\section{Brushless DC}

- Kebutuhan servo : 4 buah

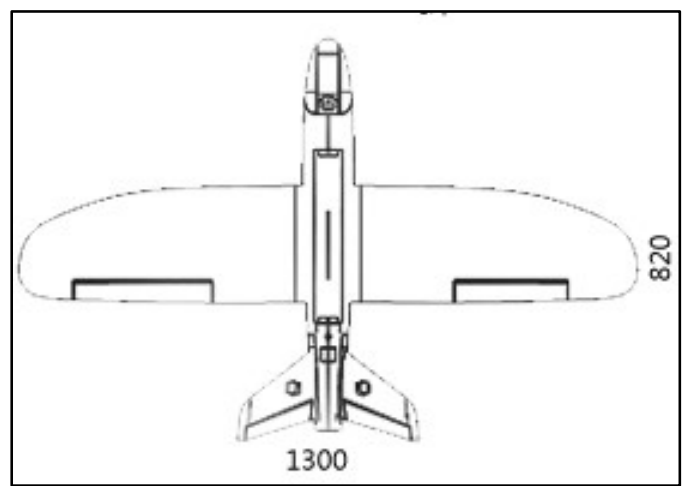

Gambar 2.1 Dimensi pesawat model XUAV Mini Talon

\subsection{Thrust test stand}

Berikut ini merupakan rencana desain serta proses pembuatan theust test stand yang dirancang dan didesain secara mandiri. Adapun alat dan bahan yang digunakan adalah sebagai berikut :

\subsubsection{Rencana desain thrust test stand}

Berikut ini merupakan rencana desain serta ukuran untuk thrust test stand yang dirancang dan didesain secara mandiri.

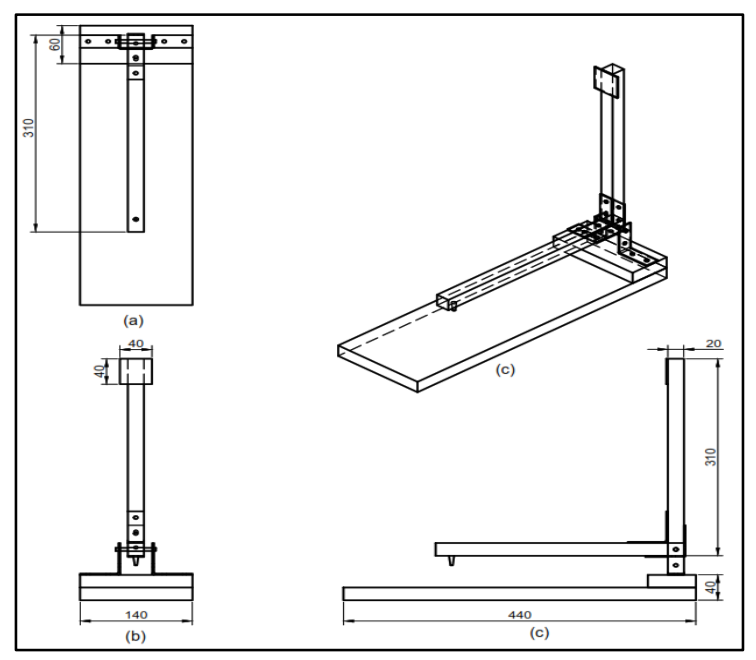

Gambar 2.2 Rencana desain serta ukuran thrust test stand. Dimana; (a) Tampak atas, (b) Tampat depan, (c) Tampak Samping, (d) Tanpak 3D

\subsubsection{Prosedur Pembuatan}

Prosedur pembuatan Thrust Test Stand dilakukan dengan langkah-langkah yang dapat dilihat pada diagram alur berikut ini :

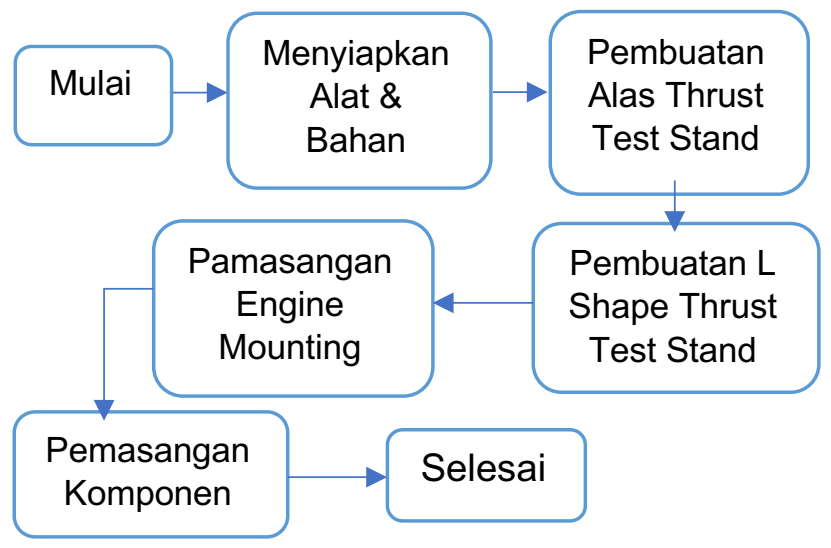

Berikut ini merupakan hasil konfigurasi serta diagram akhir thrust test stand 
setelah semua bahan dan komponen listrik dirakit.

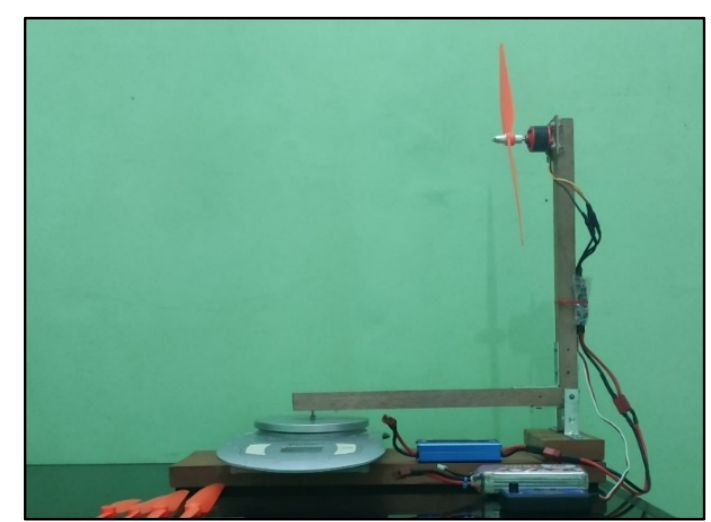

Gambar 2.3 Konfigurasi akhir dari thrust test stand

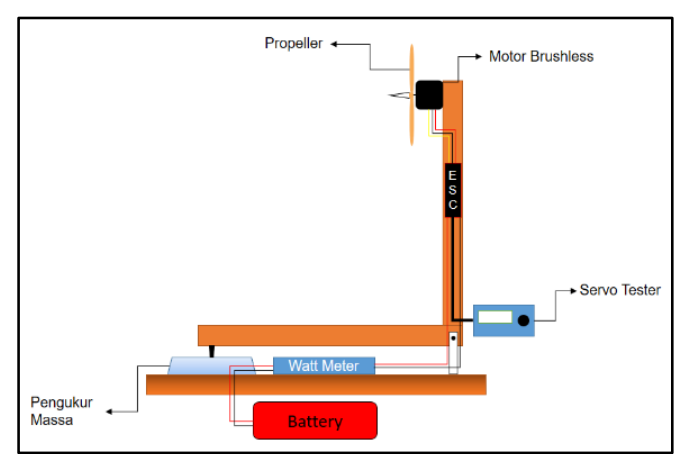

Gambar 2.4 Diagram skematik thrust test stand

\subsection{Spesifikasi Motor Brushless dan \\ Propeller}

Berikut ini merupakan spesifikasi dari motor brushless yang digunakan dalam penelitian.

Tabel 2.1 Spesifikasi motor brushless ${ }^{[7][8]}$

\begin{tabular}{|l|l|l|l|}
\hline $\begin{array}{c}\text { Model } \\
\text { Brushless }\end{array}$ & Kv & Baterai & Berat \\
\hline $\begin{array}{l}\text { Racerstar } \\
\text { BR2212 }\end{array}$ & 1400 & $\begin{array}{l}3-4 S \\
\text { LiPo }\end{array}$ & $\begin{array}{l}55 \\
\text { gram }\end{array}$ \\
\hline $\begin{array}{l}\text { DYS G- } \\
\text { Power } \\
\text { 2826-13 }\end{array}$ & 1000 & $\begin{array}{l}2-4 S \\
\text { LiPo }\end{array}$ & $\begin{array}{l}55 \\
\text { gram }\end{array}$ \\
\hline
\end{tabular}

Untuk propeller digunakan propeller dengan menggunakan propeller GWS dengan diameter dan pitch sebagai berikut.

Tabel 2.2 Spesifikasi propeller

\begin{tabular}{|l|c|c|}
\hline $\begin{array}{l}\text { Model } \\
\text { Propeller }\end{array}$ & Diameter & Pitch \\
\hline Prop 1 & 5 & 3 \\
\hline Prop 2 & 7 & 3,5 \\
\hline Prop 3 & 8 & 4 \\
\hline Prop 4 & 9 & 5 \\
\hline Prop 5 & 10 & 6 \\
\hline
\end{tabular}

\section{HASIL DAN PEMBAHASAN}

\subsection{Perhitungan Gaya Dorong yang Dibutuhkan}

Berdasarkan data yang didapat berat kosong pesawat X-Uav Mini Talon adalah 550 gram. $^{[9]}$ Dari berat kosong tersebut dimasukkan komponen-komponen penggerak flight control, sistem propulsi dan juga sistem untuk pengambilan gambar udara. Total berat komponenkomponen serta payload adalah sebesar 650 gram. Berdasarkan persamaan berat pesawat terbang, berat masing-masing komponen dijumlahkan dan akan menghasilkan berat terbang pesawat. Dimana masing-masing berat payload adalah :

Dari persamaan Weight maka total Weight adalah :

$$
\begin{aligned}
& \text { Weight }=\text { Berat Kosong }+ \text { Payload } \\
& \text { Weight }=550 \mathrm{~g}+650 \mathrm{~g} \\
& \text { Weight }=1.200 \mathrm{~g}
\end{aligned}
$$

Maka Weight dalam Newton adalah sebesar

$$
\begin{aligned}
& \text { Weight }=1.200 \mathrm{~g} \cdot 9,81 \mathrm{~m} / \mathrm{s}^{2} \\
& \text { Weight }=1,2 \mathrm{~kg} \cdot 9,81 \mathrm{~m} / \mathrm{s}^{2}
\end{aligned}
$$


Jurnal Teknologi Kedirgantaraan, Vol, V No. 2, Agustus 2020, P-ISSN 2528-2778, E-ISSN 2684-9704 https://doi.org/10.35894/jtk.v5i2.16

$$
\text { Weight }=11,772 \mathrm{~N}
$$

Dari data diatas didapatkan total Weight pesawat X-UAV Mini Talon adalah 1.200 gram. Dimana berat tersebut sudah termasuk semua komponen-komponen yang dibutuhkan untuk mengontrol pesawat dan juga untuk sistem pengambilan gambar. Berdasarkan berat tersebut akan dihitung kebutuhan gaya dorong minimal untuk pesawat X-UAV Mini Talon dalam keadaan terbang jelajah (cruise). Dengan spesifikasi pesawat diatas, didapatkan juga luas sayap (S) sebesar $30 \mathrm{dm}^{2}$ atau sama dengan 0,3 $\mathrm{m}^{2}$. [9]

Berdasarkan persamaan (2.4) dapat dihitung besarnya koefisien lift adalah sebagai berikut :

$$
C_{L}=\frac{2 L}{\rho \cdot V^{2} \cdot S}
$$

Bila diasumsikan kecepatan pesawat (V) yaitu $15 \mathrm{~m} / \mathrm{s}$ maka,

$$
\begin{aligned}
C_{L} & =\frac{2 \cdot 11,772 \mathrm{~N}}{1,225 \mathrm{~kg} / \mathrm{m}^{3} \cdot(15 \mathrm{~m} / \mathrm{s})^{2} \cdot 0,3 \mathrm{~m}^{2}} \\
C_{L} & =\frac{23,544 \mathrm{~N}}{1,225 \mathrm{~kg} / \mathrm{m}^{3} \cdot 225 \mathrm{~m}^{2} / \mathrm{s}^{2} \cdot 0,3 \mathrm{~m}^{2}} \\
C_{L} & =\frac{23,544}{82,6875} \\
\boldsymbol{C}_{\boldsymbol{L}} & =\mathbf{0 , 2 8 4 7} \\
\boldsymbol{C}_{\boldsymbol{L}} & \approx \mathbf{0 , 2 9}
\end{aligned}
$$

Dengan diketahuinya $C_{L}$ maka dapat dihitung $C_{D}$ dengan persamaan (2.15). Berdasarkan spesifikasi pesawat ${ }^{[9]}$, maka diketahui aspect ratio sayap adalah sebesar :

$$
\begin{aligned}
A & =\frac{b^{2}}{S} \\
A & =\frac{1,3^{2}}{0,3} \\
A & =\frac{1,69}{0,3}
\end{aligned}
$$

$$
A=5,63
$$

Sedangkan berdasarkan data dari NACA 2415, diketahui bahwa pada saat $C_{L}$ sebesar 0,29 besarnya $C_{D 0}$ adalah 0,0105. Maka dengan menggunakan persamaan (2.16) didapatkan besarnya $C_{D}$ adalah :

$$
\begin{aligned}
& C_{D}=C_{D 0}+\frac{C_{L}^{2}}{\pi \cdot A \cdot e} \\
& C_{D}=0,01+\frac{0,29^{2}}{3,14 \cdot 5,63 \cdot 0,75} \\
& C_{D}=0,01+\frac{0,0841}{13,258} \\
& C_{D}=0,01+0,00634 \\
& C_{\boldsymbol{D}}=\mathbf{0 , 0 1 6 3 4}
\end{aligned}
$$

Dengan diketahui $C_{D}$ sebesar 0,01634 , maka bisa dihitung besaran drag pada saat jelajah dengan persamaan (2.16)

$$
\begin{aligned}
& D=\frac{C_{d} \cdot \rho \cdot V^{2} \cdot S}{2} \\
& D \\
& =\frac{0,01634 \cdot 1,225 \mathrm{~kg} / \mathrm{m}^{3} \cdot(15 \mathrm{~m} / \mathrm{s})^{2} \cdot 0,3 \mathrm{~m}^{2}}{2} \\
& D=\frac{1,351}{2} \mathrm{~N} \\
& \boldsymbol{D}=\mathbf{0 , 6 7 5 5} \mathbf{N}
\end{aligned}
$$

Dari hasil perhitungan diatas didapatkan bahwa gaya dorong yang diperlukan untuk terbang jelajah 0,6755 N. Gaya dorong tersebut adalah gaya dorong yang dibutuhkan pada saat pesawat terbang dalam keadaan steady and level flight. Pada pengujian kali ini, untuk mencari $\mathrm{C}_{\llcorner\mathrm{m}}$ maka digunakan $V_{\text {stall }}$ pesawat. $V_{\text {stall }}$ diasumsikan sebesar $10 \mathrm{~m} / \mathrm{s}$. Maka didapatkan $\mathrm{C}_{\mathrm{Lm}}$ sebesar :

$$
\begin{aligned}
C_{L m} & =\frac{2 \cdot 11,772 \mathrm{~N}}{1,225 \mathrm{~kg} / \mathrm{m}^{3} \cdot(10 \mathrm{~m} / \mathrm{s})^{2} \cdot 0,3 \mathrm{~m}^{2}} \\
C_{L m} & =\frac{23,544 \mathrm{~N}}{1,225 \mathrm{~kg} / \mathrm{m}^{3} \cdot 100 \mathrm{~m}^{2} / \mathrm{s}^{2} \cdot 0,3 \mathrm{~m}^{2}}
\end{aligned}
$$


Jurnal Teknologi Kedirgantaraan, Vol, V No. 2, Agustus 2020, P-ISSN 2528-2778, E-ISSN 2684-9704 https://doi.org/10.35894/jtk.v5i2.16

$C_{\text {Lm }}=\frac{23,544}{36,75}$
$C_{\text {Lm }}=\mathbf{0 , 6 4}$

Nilai $C_{\llcorner m}$ didapatkan sebesar 0,64 . Maka gaya dorong untuk pesawat dapat take-off apabila $S_{T}$ diasumsikan $30 \mathrm{~m}$ adalah

$$
\begin{aligned}
\frac{T}{W} & =\frac{\frac{1,44 \cdot W / S}{\rho \cdot g \cdot C_{L m}}}{S_{T}-1,2 \cdot t_{r} \cdot \sqrt{\frac{2 \cdot W / S}{\rho \cdot C_{L m}}}} \\
\frac{T}{W} & =\frac{1,44 \cdot \frac{11,772 \mathrm{~N}}{0,3 \mathrm{~m}^{2}}}{1,225 \mathrm{~kg} / \mathrm{m}^{3} \cdot 9,81 \mathrm{~m} / \mathrm{s}^{2} \cdot 0,64} \\
\frac{T}{W} & =\frac{2 \cdot \frac{11,772 \mathrm{~N}}{0,3 \mathrm{~m}^{2}}}{30 \mathrm{~m}-12,006 \mathrm{~m}} \\
\frac{T}{W} & =\frac{7,346 \mathrm{~m}}{17,993 \mathrm{~m}} \\
\frac{T}{W} & =0,423
\end{aligned}
$$

Dengan berat pesawat $11,772 \mathrm{~N}$, maka gaya dorong untuk take-off adalah

$$
\begin{aligned}
& T=0,423.11,772 N \\
& \boldsymbol{T}=\mathbf{4}, \mathbf{9 7 9} \boldsymbol{N}
\end{aligned}
$$

dengan demikian, dibutuhkan gaya dorong sebesar 4,979 $\mathrm{N}$ untuk pesawat dapat take-off.

\subsubsection{Hasil Pengujian}

Pengujian untuk mendapatkan gaya dorong dilakukan sebanyak tiga kali dengan kondisi yang sama. Berikut ini merupakan hasil dari tiga kali pengujian ini. Berdasarkan hasil dari tiga kali pengujian,

\begin{tabular}{|c|c|c|c|c|c|}
\hline \multirow[b]{2}{*}{ 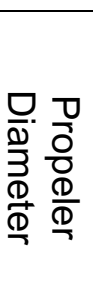 } & \multirow[b]{2}{*}{ 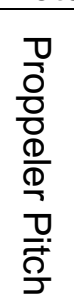 } & \multicolumn{4}{|c|}{ DYS 2826-13 Motor Brushless } \\
\hline & & 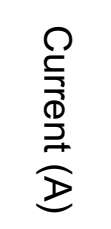 & 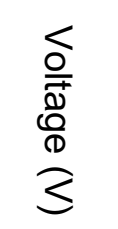 & 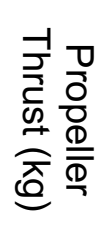 & 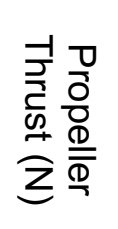 \\
\hline 5 & 4,5 & 2,00 & 12,11 & 0,101 & 0,988 \\
\hline 7 & 3,5 & 3,10 & 8,21 & 0,232 & 2,273 \\
\hline 8 & 4 & 6,01 & 11,92 & 0,464 & 4,555 \\
\hline 9 & 5 & 10,82 & 11,33 & 0,627 & 6,151 \\
\hline 10 & 6 & 11,47 & 11,63 & 0,753 & 7,384 \\
\hline
\end{tabular}
didapatkan hasil rata-rata gaya dorong dari masing-masing konfigurasi antara motor brushless dan propeller sebagai berikut

\begin{tabular}{|c|c|c|c|c|c|}
\hline \multirow[b]{2}{*}{ 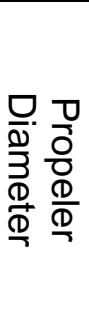 } & \multirow{2}{*}{ 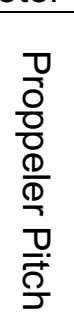 } & \multicolumn{4}{|c|}{$\begin{array}{c}\text { RacerStar BR2212 Motor } \\
\text { Brushless }\end{array}$} \\
\hline & & 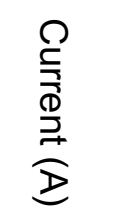 & 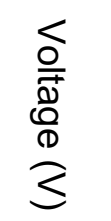 & 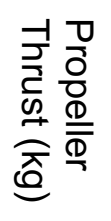 & 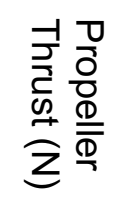 \\
\hline 5 & 4,5 & 4,48 & 11,72 & 0,194 & 1,906 \\
\hline 7 & 3,5 & 7,28 & 11,44 & 0,435 & 4,264 \\
\hline 8 & 4 & 13,03 & 10,98 & 0,727 & 7,135 \\
\hline 9 & 5 & 21,17 & 10,52 & 0,863 & 8,466 \\
\hline 10 & 6 & 23,54 & 10,48 & 1,070 & 10,500 \\
\hline
\end{tabular}
yang ditampilkan pada Tabel 3.2 dan Tabel 3.3.
Tabel 3.1 Rata-rata hasil gaya dorong motor brushless DYS 2826-13

Tabel 3.2 Rata-rata hasil gaya dorong motor brushless RacerStar BR2212

Dari hasil pengujian di atas didapatkan bahwa gaya dorong yang terkecil didapatkan dari konfigurasi antara motor brushless DYS 2826-13 dengan menggunakan propeller berdiameter 5 inch dan pitch 3 inch. Konfigurasi tersebut dialiri arus listrik rata-rata sebesar 2,00 A serta tegangan listrik rata-rata sebesar 12,11 volt. Sedangkan gaya dorong terbesar didapatkan dari konfigurasi antara motor brushless RacerStar BR2212 dengan menggunakan propeller berdiameter 10 
Jurnal Teknologi Kedirgantaraan, Vol, V No. 2, Agustus 2020, P-ISSN 2528-2778, E-ISSN 2684-9704

https://doi.org/10.35894/jtk.v5i2.16

inch dan pitch 6 inch. Konfigurasi tersebut dialiri arus listrik rata-rata sebesar 23,54 A dan tegangan listrik rata-rata sebesar 10,48 volt.

\subsubsection{Perbandingan hasil gaya dorong \\ Pengujian alat thrust test stand} berfungsi untuk mengetahui apakah alat tersebut telah tervalidasi dengan baik atau perlu kalibrasi ulang. Pada pengujian alat, digunakan dua buah propeller yang memiliki diameter yang berbeda. Hasil gaya dorong yang didapat akan dibandingkan dengan perhitungan gaya dorong statis propeller dengan menggunakan persamaan 2.23. Pada pengujian dibutuhkan anemometer untuk mengetahui kecepatan udara yang keluar dari propeller. Anemometer yang digunakan untuk mengukur kecepatan udara yang keluar dari propeller diletakkan dengan jarak antara $3 \mathrm{~cm}$ sampai $5 \mathrm{~cm}$ dari propeller. Setelah melakukan pengujian maka didapatkan gaya dorong dan kecepatan udara dibelakang propeller sebagai berikut :

Tabel 3.3 Hasil gaya dorong pada pengujian alat thrust test stand

\begin{tabular}{|l|c|c|}
\hline Prop & $\begin{array}{c}\text { Rata-rata } \\
\text { Thrust } \\
\text { Pengujian } \\
(\mathrm{kg})\end{array}$ & $\begin{array}{c}\text { Rata-rata } \\
\text { Thrust } \\
\text { Pengujian } \\
(\mathrm{N})\end{array}$ \\
\hline $5 \times 3$ & 0,101 & 0,988 \\
\hline $7 \times 3,5$ & 0,232 & 2,273 \\
\hline
\end{tabular}

Tabel 3.4 Hasil kecepatan udara exit propeller

\begin{tabular}{|l|r|r|r|r|}
\hline Prop & $\begin{array}{c}\text { Ve 1 } \\
(\mathrm{m} / \mathrm{s})\end{array}$ & $\begin{array}{c}\text { Ve 2 } \\
(\mathrm{m} / \mathrm{s})\end{array}$ & $\begin{array}{r}\text { Ve 3 } \\
(\mathrm{m} / \mathrm{s})\end{array}$ & $\begin{array}{r}\text { Rata-rata } \\
\text { Ve }(\mathrm{m} / \mathrm{s})\end{array}$ \\
\hline $5 \times 3$ & 10,7 & 10,1 & 10 & 10,267 \\
\hline $7 \times 3,5$ & 11,1 & 10,4 & 11,2 & 10,9 \\
\hline
\end{tabular}

Dari data pada Tabel 3.10 dan Tabel 3.11 maka didapatkan rata-rata dari gaya dorong pada pengujian adalah sebesar $0,988 \mathrm{~N}$ pada propeller dengan diameter 5 inch dan $0,273 \mathrm{~N}$ pada propeller dengan diameter 7 inch. Sedangkan rata-rata kecepatan yang diakselerasi oleh propeller adalah sebesar $10,26 \mathrm{~m} / \mathrm{s}$ pada peopeller dengan diameter 5 inch dan 10,9 m/s pada propeller dengan diameter 7 inch. Dengan persamaan 2.13 maka didapatkan besarnya gaya dorong statis dari dua buah propeller adalah sebagai berikut :

- Propeller 5x3

$T_{p \text { static }}=0,5 \cdot \rho \cdot A \cdot\left(V_{e}^{2}-V_{0}^{2}\right)$

$T_{p \text { static }}=0,817 \mathrm{~N}$

- Propeller $7 \times 3,5$

$T_{p_{\text {static }}}=0,5 \cdot \rho \cdot A \cdot\left(V_{e}^{2}-V_{0}^{2}\right)$

$T_{\text {pstatic }}=1,806 \mathrm{~N}$

Apabila dibandingkan dengan gaya dorong yang didapat dari pengujian maka didapatkan selisih gaya dorong dari masing-masing propeller yang ditunjukkan pada Tabel 3.12.

Tabel 3.5 Perbandingan thrust pengujian dan thrust static propeller

\begin{tabular}{|c|c|c|c|c|}
\hline Prop & 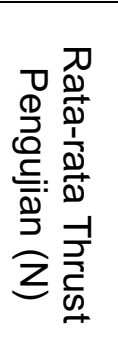 & 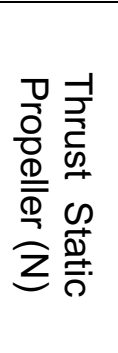 & 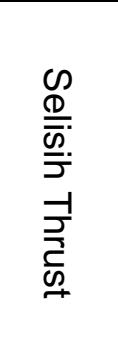 & 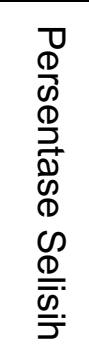 \\
\hline $5 \times 3$ & 0,988 & 0,817 & 0,170 & $17 \%$ \\
\hline $7 \times 3,5$ & 2,273 & 1,806 & 0,467 & $21 \%$ \\
\hline
\end{tabular}

Dari hasil perbandingan diatas maka didapatkan persentase selisih dari perbandingan antara gaya dorong pada 
pengujian dengan gaya dorong statis propeller berkisar antara $15 \%$ sampai $25 \%$. Selisih tersebut disebabkan karena pengujian untuk kecepatan udara exit propeller tidak dilakukan pada wind tunnel, hal tersebut menyebabkan masih adanya gangguan yang mengakibatkan udara tidak terpusat ke anemometer. Maka dari itu, antara gaya dorong hasil pengujian dengan gaya dorong hasil perhitungan menggunakan persamaan gaya dorong statis propeller masih terjadi selisih sebagai mana pada Tabel 3.12.

\subsection{Pengujian estimasi daya tahan baterai}

Pada pengujian estimasi baterai yang digunakan, didapatkan lamanya baterai $1800 \mathrm{mAh}$ dapat menyuplai arus listrik sebesar 2 A selama 43 menit. Sedangkan berdasarkan persamaan (2.24) lamanya baterai dapat menyuplai arus listrik adalah :

time $=\frac{Q}{I}$

time $=\frac{1800 m A h}{2 A .1000}$

time $=0,9 \mathrm{jam}$

time $=54$ menit

Maka didapatkan perbandingan antara waktu aktual dan waktu perhitungan adalah sebagai berikut

efisiensi $=\frac{\text { waktu aktual }}{\text { waktu perhitungan }} \cdot 100 \%$

efisiensi $=\frac{43}{54} .100 \%$

efisiensi $=79,62 \% \approx 80 \%$

\subsection{Pemilihan Konfigurasi yang Sesuai \\ Berdasarkan hasil tiga kali pengujian,} maka didapatkan gaya dorong yang dibutuhkan untuk pesawat X-UAV Mini Talon terbang jelajah (level flight) adalah sebesar $0,6755 \mathrm{~N}$. Maka konfigurasi yang cukup untuk menghasilkan gaya dorong tersebut adalah konfigurasi antara motor brushless DYS 2826-13 menggunakan propeller beriameter 5 inch dan pitch 3 inch. Konfigurasi tersebut menghasilkan gaya dorong sebesar 0,988 N. Untuk menghasilkan gaya dorong tersebut, konfigurasi ini membutuhkan arus listrik sebesar 2,00 A dan tegangan listrik sebesar 12,11 volt.

Sedangkan untuk take-off pesawat XUAV Mini Talon membutuhkan gaya dorong sebesar 4,979 N. Maka konfigurasi yang cukup untuk gaya dorong tersebut adalah motor Brushless DYS 2826-13 dengan propeller berdiameter 9 inch dan pitch 5 inch. Konfigurasi tersebut menghasilkan gaya dorong sebesar 6,151 N. Untuk menghasilkan gaya dorong tersebut, konfigurasi ini membutuhkan arus listrik sebesar 10,82 A dan tegangan listrik sebesar 11,32 volt.

Konfigurasi tersebut dipilih karena membutuhkan arus listrik yang lebih kecil dimana lebih efisien dibandingkan konfigurasi lain yang menghasilkan gaya dorong yang kurang lebih setara. Berdasarkan persamaan (2.24), untuk menghitung waktu yang dapat ditempuh dengan kapasitas betrai $1800 \mathrm{mAh}$ yang mengaliri arus listrik sebesar 10,9 A adalah sebagai berikut.

$$
\begin{aligned}
\text { time } & =\frac{Q}{I} \cdot \text { perbandingan } \\
\text { time } & =\frac{1800}{10,82 \cdot 1000} \cdot 80 \% \\
\text { time } & =\frac{1800}{10820} \cdot 80 \% \\
\text { time } & =0,166 \cdot 80 \% \\
\text { time } & =0,1328 \mathrm{jam} \\
\text { time } & =7,96 \text { menit }
\end{aligned}
$$

\section{Kesimpulan}


Jurnal Teknologi Kedirgantaraan, Vol, V No. 2, Agustus 2020, P-ISSN 2528-2778, E-ISSN 2684-9704 https://doi.org/10.35894/jtk.v5i2.16

Dari hasil penelitian pada bab sebelumnya, diambil beberapa kesimpulan yang dapat dijadikan hal pokok dari penulisan tugas akhir ini, antara lain :

1. Gaya dorong terkecil dihasilkan oleh konfigurasi motor brushless DYS 2826-13 dengan propeller $5 \times 3$ inch, sedangkan gaya dorong terbesar oleh motor brushless RacerStar BR2212 dengan propeller 10x6 inch.

2. Selisih dari hasil gaya dorong pada pengujian dengan gaya dorong statis propeller berkisar antara 15\% sampai $25 \%$. Selisih tersebut disebabkan karena pengujian tidak dilakukan di wind tunnel yang mengakibatkan adanya gangguan, sehingga udara tidak terpusat ke anemometer.

3. a) Konfigurasi yang optimal dan efisien dengan kebutuhan arus yang kecil untuk pesawat model $X$ UAV Mini Talon pada terbang jelajah adalah motor brushless DYS 2826-13 dengan propeller $5 \times 3$ inch, yang menghasilkan gaya dorong sebesar $0,988 \mathrm{~N}$.

b) Konfigurasi yang optimal dan efisien dengan kebutuhan arus kecil untuk pesawat model X-UAV Mini Talon dapat take-off adalah Brushless DYS 2826-13 dengan propeller 9x5 inch, yang menghasilkan gaya dorong sebesar $6,151 \mathrm{~N}$.

\section{DAFTAR PUSTAKA}

[1] Jakubowski, A. 2015. Analysis Thrust for Different Kind of Propellers. Institute of Mechanical Technology, Poznan University of Technology, Poznan.

[2] Wiratama, C. 2016. Pesawat Remote Control

(Aeromodelling). http://aeroengineering.co.id/2016/01/p esawat-remot-kontrol-aeromodelling/, diakses pada 23 Maret 2019.

[3] Renesas Electronics Corporation. 2015. What are Brushless DC Motors. https://www.renesas.com/in/en/suppo rt/technical-resources/engineerschool/brushless-dc-motor-01overview.html, diakses pada tanggal 10 Maret 2019.

[4] Liklikwatil, Y. 2012. Mesin-mesin Listrik untuk program D3. Deepublish, D.I. Yogyakarta.

[5] Husaini, A.N. 2015. Prinsip Kerja Motor Brushless DC (BLDC Motor). http://www.insinyoer.com/prinsipkerja-motor-brushless-dc-bldcmotor/2/, diakses pada tanggal 12 Maret 2019.

[6] Wiratama, Caesar. 2016. Propeller Pesawat Aeromodelling. http://aeroengineering.co.id/2016/03/p ropeller-pesawat-aeromodelling/, diakses pada tanggal 23 Maret 2019.

[7] Racerstar Electronic Technology. 2018. Racerstar BR2814 1400KV 34S Brushless Motor For RC Airplane Model.

https://www.racerstar.com/RacerstarBR2814-1400KV-3-4S-Brushless-

Motor-For-RC-Airplane-Model-p291.html, diakses pada tanggal 25 Maret 2019.

[8] DongYang Smart Technology. 2018. D2826-13 1000kv Brushless Motor http://www.dys.hk/product/D2826.html, diakses pada tanggal 28 Mei 2019.

[9] HOOAH Aviation Technology CO. 2015. X-UAV fat fixed wing aircraft FPV. $\quad h$ ttp://www.xuav.cn/en/content/?465.html, diakses pada tanggal 4 Maret 2019. 
Jurnal Teknologi Kedirgantaraan, Vol, V No. 2, Agustus 2020, P-ISSN 2528-2778, E-ISSN 2684-9704 https://doi.org/10.35894/jtk.v5i2.16

[10] Saarlas, M. 2007. Aircraft Performance. John Wiley \& Sons, Inc., California.

[11] Ruijgrok, G.J.J. 1994. Elements of Airplae Performance. Delft University Press, Delft.
[12] Raymer, D.P. 2006. Aircraft Design : A Conceptual Approach, Fourth Edition. AIAA, Inc., Washington D.C. 